\title{
Editorial: Actual politics and the need of conceptual clarity
}

\section{The Primacy of the Sociopolitical Dimension and Its Contradictions}

The challenge of sustainability of all forms of life on this planet concerns directly the actors, agencies, and other forms of the sociopolitical/legal dimension of societies. This has been confirmed by all members of the BRICS nations (Brazil, Russia, India, China, and South Africa) in the past decade, who said to follow the 2030 Agenda for Sustainable Development of the UN (2015). As argued by Marco Ricceri (2019), with the Paris Agreement in mind, these member states presented a self-imposed and relevant assignment, which will or should function as their frame of reference. His analysis of the recent history of this platform was also based on the current characteristics of the social quality approach which also are relevant for this editorial (IASQ 2019). In the fall of 2019, the new European Commission (EC 2019/a) also clearly said in its document about the European Green Deal that it would propose and elaborate radical measures to contribute to the development of the overall sustainability:

\footnotetext{
The most ambitious package of measures that should enable European citizens and businesses to benefit from sustainable green transition. Measures accompanied with an initial roadmap of key policies range from ambitiously cutting emissions, to investing in cuttingedge research and innovation, to preserving Europe's natural environment.
}

According the EC (2019/b: 3), the quintessence of this deal is to transform the EU's economy for a sustainable future, which includes, for example, a zero-pollution for a toxic free environment; farm-to-table, namely, a fair, healthy, and environmentally friendly food system; a supply of clear, affordable, and secure energy; and eight other priorities. The aim is for the EU-as an embodiment of, in particular, the joint sociopolitical/legal configuration of its member states - to regain authority over climate politics for its part of the world. In line with this, Basil Oberholzer (2019) argues, "it is wrong to believe the financial sector will contribute to ecological transformation ... Sustainable finance rests on the idea that money needs to be used for good, [but] astonishing amounts of private wealth are invested in the wrong assets or remain idle." And indeed, according the Center for International Environmental Law, over the coming five years, the oil and gas sector intends to invest $\$ 1.4$ trillion in developing new oil and gas extraction. About 85 percent of global oil and gas expansion are in North America, but 
if your house is on fire you don't add more fuel. Expanding production of oil and gas at this moment in history is like the fire department showing up with gas rather than water to save a planet on fire ... Leadership in the face of a climate emergency means no fossil fuel exploration, new expansion, or financing paired with an ambitious and just transition away from oil and gas production. (CIEL 2019)

Jonathan Watts and colleagues (2019) of The Guardian add that Shell, Exxon Mobil, and Gazprom will be among the leaders, "with a projected production increase of more that 35 percent between 2018 and 2030 - a sharper rise than over the previous 12 years. The acceleration is almost the opposite of the 45 percent reduction in carbon emission by 2030." In an interview with the Friends of the Earth Netherlands, Shell's highest executive confirmed that big players also aim to retain shareholders. And, for many other reasons, this NGO started a lawsuit against Shell, "the largest polluter in the Netherlands" (Milieudefensie 2018). The thesis posits that especially actors and agencies of the sociopolitical/legal dimension provide political opportunities for actors and agencies of the socioeconomic/financial dimension to determine how they can guarantee profit for shareholders, how to increase salaries of the top of their companies, and to favor "political friends" by whatever means. If true, the usual assumed dependence on global processes of actors and agencies in the socioeconomic/financial dimension is untenable. The current Republican administration of the United States make this thesis indeed acceptable. Karen Clay and Nicholas Muller (2019) concluded based on empirical research that after years of improvement, US air quality has worsened since 2016 because of the political primacy, resulting in an increase of wildfires and fossil-based economic activities and an ostentatious decrease in Clean Air Act enforcement actions of federal regulations. As Paul Krugman (2019) argues, this is an outcome of the recent administration's politically oriented antienvironmental protection, next to the consequences of its coal, oil, and gas politics: "If [US President Donald] Trump stays in office, a lot more Americans will die as a result of his anti-environmental policies than the total number who are murdered, let alone murdered by immigrants Trump loves to portray as a menacing, dark-skinned horde."

Notwithstanding the current frame of reference of the BRICS nations and its orientation on UN studies and proposals, it can be noted that some relevant political decisions of these nations are at odds with this framework. If governments must limit the increase in temperature as a result of climate change to less than 2 degrees Celsius, then coal consumption will have to be reduced far more dramatically than is currently forecast (e.g., UNEP 2019). But according to the Institute for Energy Economics and Financial analysis, "in practical terms, the future of coal is largely in the hands of just two countries, China and India, which currently account for 60.2 percent of global electricity generated by the polluting fuel ... and this is seriously increasing till 2040" (Russell 2019). And of course, Brazil's current politics on the Amazon is outright against the BRICS-accepted UN framework (Watts 2019). And as Tim Cadman and colleagues (2019) have concluded, during the 2015 UN Climate Change Conference 
concerning the negotiations in Poland, decarbonization remained the major political challenge but was not supported by fossil-fuel-rich countries like the United States and also Russia. And the contradictions concerning the EU's environmental politics cannot be underestimated either. Independently of the recent Green Deal, the EU is paying out about 60 billion euros of farm subsidies, nearly 40 percent of its budget. About the consequences of these subsidies in recent decades, the New York Times published the outcomes of two eye-catching studies. The first, from November 2019, demonstrates that across Hungary and much of Central and Eastern Europe, the bulk goes to a connected and powerful few. The right-wing prime ministers of the Czech Republic and Hungary collected tens of millions of euros for themselves, their families, and their political friends:

Europe's machinery in Brussels enables this rough-hewed corruption because confronting it would mean changing a program that helps hold a precarious union together. European leaders disagree about many things, but they all count on generous subsidies and wide discretion in spending them . . The European Union maintains a master database but, citing the difficulty of downloading the requested information, refused to provide The Times a copy. In response, the Times compiled its own database that, while incomplete, supplemented publicly available information on subsidy payments. (Gebrekidan et al. 2019)

The second study, from December 2019, tries to demonstrate that the EU subsidies paid to farmers is just causing significant environmental harm, directly contrary to the objectives of its Green Deal. Examples include decaying algae that belch deadly gas onto beaches in Northwest France, dwindling bird populations that threaten the balance of entire ecosystems, rising greenhouse gas emissions from agriculture all over the European Union, and, in the Baltic Sea, decades of farm runoff that helped create huge dead zones. Concluded is, for example:

Farming accounts for about 10 percent of Europe's greenhouse gas emissions. A significant share of the emissions comes from farm animals that digest their feed and burp out methane, a potent greenhouse gas ... This year, Dutch lawmakers proposed halve the number of livestock in order to reduce emissions. Farmers responded by clogging the streets of The Hague with tractors, creating what some described as the worst rush hour in Dutch history . . . [acknowledged is in Britain that] for years, officials and farmers did not accept any link between agricultural practices and the green glop washing ashore. (Apuzzo et al. 2019)

\section{The Subject of the Five Articles of This Issue and the question of assumptions}

Because of major societal changes at the sociopolitical and therefore socioeconomic level in particular, the subject of public health (see Ohtman and Darrow this issue) is gaining considerably in importance. First of all, because of visible and invisible 
climate change and threats in different large regions of the world, people's daily circumstances worsen considerably. The plea from some governments for "my country first" is totally perverse with this in mind. This is made worse by increasing wealth gaps: the income going to the richest 1 percent of households has nearly tripled in the past four decades, creating a precarious multitude. In other words, the other 99 percent can expect (ceteris paribus) economic insecurity and incomprehensible differences in income, professional occupations, education, health care, welfare provisions, housing mutual care, and labor perspectives (OXFAM 2018). According to the IMF, Ukraine is the most equal nation, while South Africa and Russia, as one of the BRICS, are the least equal (Partington 2019). And the apparent untouchable laws allow great wealth to pass from generation to generation with little or no tax, organizing loopholes that corporations and the rich exploit to reduce their taxes even more, opaque structures and forms of global crime. This profound current dilemma has recently been addressed by Branko Milanovic: "When money becomes established as the sole criterion by which success is judged (as is the case in hypercommercialized societies), other hierarchical markers vanish ... discarding the competitive and acquisitive spirit that is hardwired into capitalism would lead to a decline in our incomes, increased poverty, deceleration or reversion of technological progress, and the loss of other advantages. . . we cannot improve our material way of life without giving full play to some of the most unpleasant traits of our nature" (Milanovic 2019: 184-85). As a respected economist he does not seem to be forced to substantiate this fundamental assumption about human nature. According to him, we have to live with capitalism. But according Joseph Stiglitz, this expression of the faith in the liberal democracy and market economies—already articulated by Francis Fukuyama—got stuck on the rocks: "we are now experiencing the political consequences of this grand deception: distrust of the elites, of the economic 'science' on which neoliberalism was based and of the money-corrupted political system that made it all possible" (Stiglitz 2019). But what has Stiglitz to say to Milanovic and vice versa? And then do they really differ about assumptions about human nature?

Nevertheless we are witnessing in the disturbing consequences of air pollution and associated periodic unbearable temperatures in, for example, Indian cities. It is called "airpocalypse". According to a Greenpeace India (2017) report, at least 1.2 million deaths occur every year because of outdoor air pollution (see also CPR 2017). Especially public health services, if adequate, play or must play an increasingly important societal role. And new technologies under control of actors and agencies of the sociopolitical/legal dimension are desired to reduce global temperatures (see Radunsky and Cadman, this issue). The rationale is to supplement to the relatively restricted attention of governments on the reduction of climate-change-inducing concentrations of carbon dioxide in order to address the consequences for the actual urban problematique. Next to this, a new step has been taken in this issue to get a better understanding of this problematique through another way. Thanks to the revision of the role of literature in the late twentieth century, moral philosophers have indicated 
persuasively that the form and style of literary texts can help explain certain concepts with a depth that argumentative prose fails to attain. A comparison between the nature of central concepts applied by Karl Marx and Amartya Sen about alienation, antagonism, sympathy, antipathy, commitment, and choice of identities are connected with the work of, respectively, Franz Kafka (Metamorphosis) and Manik Bandyopadhyay (Ekannoborti) (see Mukhopadhyay, this issue).

This procedure may also shed new light on the academically oriented and therefore restricted treatment of law and human rights (see Herrmann, this issue). Peter Herrmann's main thesis is that the dominant debates on human rights are caught in their stasis, and they remain perhaps even more static if they aim on developing a dynamic view. Leading representatives are unable to grasp essential dynamics in current societies and the encompassing reciprocity of these dynamics. All four articles demonstrate that more clarity should emerge about the explicit and implicit assumptions that are at stake in the communication about their subjects. What is the ontological and epistemological embedding of these assumptions? With help of the case of precarization in labor conditions, an endeavor is made to increase our understanding of this embedding (see Hepp in this issue). Much attention is dedicated to the ontological and epistemological dimensions of the French and German sociological approaches of precarization in labor conditions. This raises the interesting question as to whether in the presentation of the differences between Marx and Sen-as presented by Mukhopadhyay - these dimensions have come to its own sufficiently to understand the differences.

\section{The Five Articles Respectively and Some of Their Contextual Aspects}

The first article, by Amani Othman and William Darrow, concerns the discrimination against women and other vulnerable groups that prevailed throughout the twentieth century in US public health. The authors conclude that this persists today as well. The article contains a historical case study about the life and times of "Typhoid Mary," an unmarried Irish Catholic immigrant woman named Mary Mallon. With the presentation of this study, a different emphasis is placed than studies on the objective or conditional factors that determine the nature of public health approach. It continues the earlier study by Darrow (2015) about the decline and disorganization of US public health, which explained the failure to control the spread of HIV in this country. This disorganization can be attributed to adherence to an inadequate biomedical model that ignores the meaning of societal relations and the herewith related subjective aspects of human existence. The discrimination against vulnerable groups in the United States can be explained from the given, that public health has lost its edge. Public health made a significant impact on human well-being, capacities, and potentials in the late nineteenth century. But since then, it has taken a back seat to biomedical 
research and therapeutic medicine. Original public health with its traditional emphasis on preventing harm has been displaced by an exorbitantly expensive and continually expanding medical care system devoted almost exclusively to restoring or rehabilitating of almost the health of well-to-do individual patients, no matter the cost. This applied methodological individualism doesn't work for vulnerable groups. The story of Mary Mallon illustrates this thesis. And argued is that it is in effect today. Being a Mexican immigrant, a Muslim, or an unattractive woman could condemn someone for similar mistreatment today. And the underlying morality paves the way for the final and crude separation of parents from their children in the transition from Mexico to the United States. The article concludes that the failure to overcome prejudice impedes the effectiveness of public health to protect infected patients and susceptible persons from harm and to interrupt disease transmission in communities. It jeopardizes the realization of social quality (IASQ 2019). This will imply more attention for the subjective conditions, which is missing in biomedical research and therapeutic medicine.

Public health, as a subject and an important policy area, was in the late 1990s already at the cradle of social quality thinking. It may be seen as a major hinge point between the so-called objective reality and the subjective reality people are coping with, so we will dedicate some extra attention to the context of the first article. Harry Nijhuis and Laurent van der Maesen (2000: 139) published a study about the philosophy of modern public health and social quality as a point of reference, writing that in the nineteenth century, the old public health oriented toward biological hygiene of urban and domestic spaces was based on natural scientific epistemology. This single scientific orientation simply cannot conceive of public as a reality of societal configurations. In this perspective, as a noun, public remains a metaphor for an aggregation of individuals. It therefore logically dismisses communities as societal configurations with specific characteristics attributable to given sociopolitical, socioeconomic, and sociocultural relationships and related norms, values, and orientations. And this caused the fact that "public health (also in the US) has lost its edge." A decade later, Paul Ward and colleagues from Australia (2011) embraced the theory of social quality as a point of departure for a new approach of public health (see also Meyer et al. 2010). This delivered for them points of departure for the application of elements of the social quality approach (SQA), to facilitate a more complex and complete understanding of the so-called positivistic oriented so called "social determinants of health" (SDH).

Thanks to their previous work, Ward et al. started to approach from a broader public health perspective societal modernizing processes in Taiwan, Hong Kong, South Korea, Japan, Australia, and Thailand. This approach has been linked to an increase in general mistrust, potentially signaling sociopolitical and socioeconomic problems and on trust in family, neighbors, strangers, foreigners, and people with a different religion (Ward et al. 2014). Three years later, Daniel Holman and Alan Walker applied also the SQA in the United Kingdom for testing the utility of this approach in explaining self-rated health as a response to arguments that the $\mathrm{SDH}$ framework lacks enough theoretical basis. They used multilevel models to analyze national English and 
Welsh data (the Citizenship Survey) to test for both individual- and neighbor-level affects. One of the conclusions is that of the conditional factor of socioeconomic security — and especially its domains of housing security, income sufficiency, and income security determinants—is especially important. Furthermore, social rights, including institutional but especially civil rights, have effects of particularly large magnitude. Therefore, the SQA offers a theoretically driven perspective on the SDH, which has important policy implications and suggests several promising avenues for future research (Hamilton and Walker 2018). In this period, Nijhuis (2017) completed his following study — with aforementioned studies and empirical explorations of public health processes in the city of The Hague in mind - on a new conceptualization of contemporary public health. Starting from the previous study (van der Maesen and Nijhuis 2000), he made interpretations of the major public health discourse in the past two centuries and a critical appraisal of influential societal tendencies, to be able to identify what today is appropriate.

He argues that in addition to the enrichment of the individualistic and positivisticoriented SDH conception with the attention for the societal based conditional factors (see the new work in Australia and the UK), attention for the subjective or constitutional factors is needed for understanding the situation of people and what they need from public health support. The story of Marry Mallon supports this position. Recent research outcomes in the United States put a big shovel on top of this. The Centers for Disease Control and Prevention reported that after a stable period from 2000 to 2007, the rate of suicide among those aged 10 to 24 has increased significantly, making suicide the second-leading cause of death in this age group (Curtin and Heron 2019). And Jane Brody (2019) interviewed experts about these outcomes, one of them concluding: "We invest heavily in crises care, which is the most expensive and least effective means of preventing suicide." The SQA may deliver an answer to the application of the methodological individualism, which denies societal causes of harm, suffering, and isolation of people. It also denies capabilities for individual people and their immediate environment and communities to go beyond this state of existence. And this is the final point of the first article, namely, that public health authorities have a major responsibility to protect susceptible members of communities under their jurisdiction from harm. And a major responsibility of government officials responsible for protecting the health and safety of community residents is to assure them that decisions are being made and carried out with honesty, integrity, and transparency. Modern public health has an obligation to improve societal conditions that stimulate health and prevent conditions that threaten health. It concerns the adage of the 1980s and 1990s to strengthen communities to deliver the right environment for this.

The second article, by Klaus Radunsky and Tim Cadman, responds to the big debate about the development of the overall sustainability and highlighting-taking into account the outcomes of this debate- with a specific perspective. It deals with the idea of reflecting sunlight away from earth and thereby reducing global temperatures through solar radiation management, or solar engineering. This new turn is proposed 
because existing measures to combat rising emissions have not been entirely successful. The argument for an extra approach is that warming from anthropogenic emissions of greenhouse gases from the preindustrial period to the present will persist for centuries and will continue to cause further long-term changes in the climate system. The article outlines emerging technologies focusing on bioenergy, carbon capture, and storage and on stratospheric aerosol injection, and explores some of the challenges they pose. The rationale for presenting this article is, first, that many of the themes outlined so far are interconnected. The authors argue it has been known for some time that climaterelated risks to migration, human security, economic precarity, public health, community care, livelihoods, water supply, and food security are projected to increase with existing and near-future levels of carbon dioxide. If the mitigation of greenhouse gases will be not enough for stabilizing or reducing the increase of temperature, the world faces the need to take additional measures. That is also the obligation, for example, to build dikes for rising water levels.

Second, it specifically addresses the position of governments on solar radiation management. This implies a new rethinking of the sociopolitical/legal configurations to tackle the problems of all humanity with a rise in temperature on global level. But many actors, agencies, and forums of the sociopolitical/legal dimension—and an increasing amount from right-wing origin - supported by specific economic interest groups obstruct concerted action, calling into question the legitimacy of intergovernmentalism as a means of global governance. That was the reason for the Swiss government, along with other 11 countries, to submit a draft resolution mandating a report on the state of research, risks, and possible governance options related to geoengineering options. This happened at the UN Environment Assembly in March 2019.The authors explained that after nearly two weeks of controversial negotiations and despite intense efforts, the Swiss government withdrew the resolution as no consensus could be reached, largely because of opposition from the United States and Saudi Arabia. Moreover, this led NGOs to claim that governments pushing for research and development were doing so in the interests of fossil fuel companies. It goes without saying that a positive attitude of governments in this time of "my country first" and the increasing mutual suspicion that led to a new rise in arms is very difficult.

The federal government of Australia presents a clear example. As Tim Cadman (2019) has said, in the context of climatic tipping points and extreme weather events, we can see this season's initial "hazard" burns were largely responsible for the fires. Some fires originated on public land, as a consequence of mandatory "fuel reduction" and targets, forcing agencies like the parks service to burn. The agencies started their burning in the traditional period (end of winter), but of course (because of climate change), this was the wrong season. Due to the fact that the Australian Federal Government and their coalition partners generally don't believe in climate change, the burn period has not been adjusted. Agencies kept on doing the same old thing, and when the fires got out of control, they extended "hazard reduction" burning to private property (as they have compulsory powers) under the guise of "protecting assets" 
(such as plantations). This was when a significant part of the remnant rainforest on the Northern Tablelands in New South Wales was destroyed. Once all these fires got out of control, the agencies switched to "back" burning, exacerbating the problem. This in turn emboldened local landowners to burn their properties (as was the case with the 30,000 hectares burned at Ebor, NSW).

Australian Prime Minister Scott Morrison, a political ally of Trump, came to power in part by defending the mining industry. He sees action on global warming as a substantial threat to the mining industry. At the top of the devastating fires, he planned to go to Hawaii for the winter holidays. New input has been desired in these current global relationships and ideologies. This was the reason to make a strong plea in the 2015 Manifesto on Climate Change of the IASQ — subscribed by four hundred scholars from all over the world—for an orchestration of the academic world:

Scholars from all continents should make a contribution to politics oriented toward sustainable development that strengthens social justice, human dignity, solidarity within and across societies and equal opportunities for all peoples of the world. The results of these efforts should be made accessible so as to stimulate and mobilize individuals, communities and policy-makers at all levels to act as positive forces in the diverse processes toward sustainable development. For the proposed orchestration of academic institutes and academics from across the world, we need "academic change-agents" in order to promote the work at conceptual and methodological levels and to communicate about the outcomes, especially to and from "grassroots-levels." (IASQ 2015: 2)

This should pave the way for strengthening the UN and to invite intergovernmental bodies as the BRICS nations and the EU in this to support the UN in the light of their own resolutions.

The underlying motive for the third article, by Simantini Mukhopadhyay, is a theme Albert Hirschman broached in 1985. He accused most economists of an excessive focus on only the first of the two elements in the fundamental tension of existence in a human society, namely, that between self and others:

Economics as a science of human behavior has been grounded in a remarkably "parsimonious" postulate: that of the self-interested, isolated individual who chooses freely and rationally between alternative course of action after computing their prospective costs and benefits. In recent decades, a group of economists has shown considerable industry and ingenuity in applying this way of interpreting the social world to a series of ostensibly noneconomic phenomena, from crime to the family, and from collective action to democracy.

He concludes that while economists have "concentrated overwhelmingly" on the self, their approach toward how people relate to others has been "simplistic" and even "contradictory" (1985: 28). And this reduction of human relationships as derived from their assumptions about human nature has resulted into the assumption of the primacy of the socioeconomic dimension in societies and at the same time the dominant 
methodological individualism in sciences. Mukhopadhyay refers to both Marx and Sen, who both—in a different way-have approached the question of transcending self-interest, rejecting this parsimonious postulate. This transcendence comes to understanding by exploring the reality of human connections. They are defined in this article "as the interrelationship or interconnection between human beings that helps transcend self-interest and fosters the sense of relatedness and solidarity." It can be noted that this definition has a high degree of affinity with assumptions underlying the theory of social quality (IASQ 2019). The article compares and contrasts Marx's and Sen's approaches to human connection and suggests class in the Marxian scheme may be interpreted as what Sen calls a "belligerent" or "bellicose" identity. At the center of this article is the way in which both handle concepts as alienation, antagonism, sympathy, antipathy, commitment, and choice of identities. According to Mukhopadhyay, a characteristic difference between the two is that Marx situates processes of alienation rightly in the nature and development of production relations. Sen remains relatively silent on the issue of alienation of labor in capitalism. Freedom of transaction, particularly in the labor market, is of crucial importance in his theory, and he has criticized the absence of freedom in the labor market in communist-ruled societies.

Notwithstanding the importance to start the debate about the similarity and differences between Marx and Sen-also in light of the dominant parsimonious postulate-and reflecting the consequences of the so-called silence of Sen, this article offers something new. It connects both Marx and Sen with the work of, respectively, two authors who belong to the world of both. The first is Franz Kafka, from Western/Middle Europe like Marx, and his work Metamorphosis. The second is Manik Bandyopadhyay, from Bengal like Sen, with his work Ekannoborti. The two texts serve as vantage points reflecting on the Marxian notions of alienation and antagonism and Sen's concepts of sympathy, antipathy, and commitment. The texts complement and sometimes transcend the theorization of the concepts of both. Metamorphosis, published in 1915, is well known all over the world. Ekannoborti was published in the mid-twentieth century in then-undivided Bengal, where Marxism and leftist politics had great resonance in literature, art, music, and theater. Sen was born in this Bengal. Where the first deeply engages with the idea of alienation as a loss of human connection, the second proposes how human connection and choice of affiliation can bolster capabilities and alienation. Of interest for the SQA is the accent in this article - and in both texts referred to—of emotions, feelings, motives, helplessness, strength, joy, and love. This also reminds us of the contribution of Ananta Giri (2011: 109) in this journal:

Our understanding of the human and the social, as well as our realization of these, are in need of fundamental transformations, as our present day use of these are deeply anthropocentric, Eurocentric, and dualistic ... [The article] pleas for a foundational rethinking of human security and social quality and for creative intertwining between the two with visions and practices of practical spirituality. 
In terms of the SQA, Giri's plea and the second article demonstrate the need to dedicate the attention to not only the objective factors determining observable aspects of our reality but also and especially the subjective factors, constituting our mind, actions, feelings and orientations.

In the fourth article, Peter Herrmann hypothesizes that current human rights research is marked by three paradigmatically different approaches, each of which embodies its own contrast. The first concerns human rights as a collective and public good and as a possibility of the unfolding of the individual. The second refers to the tension between positive law as in itself valuable and veritable and law as outcome of a moral position, the third as an orientation and as a standard. Of interest is how to understand in paradigmatic sense these three pairs of contrast. According to Herrmann, for discussing and designing human rights that matter, it should be connected with realities today. In that case, we must introduce in human and societal sciences the terms "relationality and processuality." These concepts resonate the reasoning of current theoretical physics. Herrmann explains this by referring to Hans-Peter Dür, who argues that matter is not made up of matter. In the end, there is no more matter: only form, shape, symmetry, relationship. It does reflect a changed setting and constellation of the given elements. This means for Herrmann that we must think carefully about Thomas Kuhn's thesis, namely that the work of most scientists inevitably is predicated on the assumption that the scientific community knows what the world is like—but also the recent insights in physics and major structural sociopolitical and socioeconomic changes as outcomes of transformation of the technological conditions (thanks to contemporary physics as well) of the production and reproduction relationships. If this common sense assumption is not sustainable, it will have consequences for the reasoning of human rights. This paves the way for rising above the three paradigmatically different approaches. Herrmann refers to the rather new situation that - thanks to recent natural sciences—we are able to think in a nonteleological way. This may review the question of what a good life is. And our new consensus about the "good life" should deliver the frame of reference of acceptable human rights.

Herrmann argues further-and this is important for reflecting the three previous articles of this issue- that up until now the function of law has been very much focused on securing the status, based on the suggested "fundamental right" to property combined with the fundamental obligation to engage in dependent work-depending on private property or work employed on the ground of property privately owned by others. This demonstrates the fundamental tension between the historical based outcomes and the contemporary structural changes. This means many aspects of the law and human rights are becoming obsolete and at the expense of the contemporary human dignity, equal value, or solidarity. And this essential theme about human right and herewith related normative factors (as discussed in the SQA) is not mentioned in connection with human nature by Milanovic, referred to above. These current societal processes produce also a profound change in morality that requests a new interpretation of human rights. That is implicated, for example, in recent politics to 
possibly destroy centuries-old cultural sites for retribution. This makes the cri de coeur of William Webster (2019) for renewing our laws and hereupon based human rights important. He has had-in his terms - the privilege of being the only American in our history to serve as the director of both the FBI and the CIA and says: "This gave me a unique perspective and a responsibility to speak about a dire threat to the rule of law in the country I love. Order protects liberty, and liberty protects order. Today, the integrity of the institutions that project our civil order is, tragically, under assault from too many people whose job it should be to protect them." His country is the most powerful country, yet it should assist countries and communities who are in need to accommodate to dangers of, for example, climate change, defend the quality of their daily circumstances, and contribute to the development of the quality of global development, the main objective of the BRIC nations. And the targeted destruction of Iranian heritage would be a war crime, as declared in the The Hague Convention of the Protection of Cultural Property of 1954, which is adopted to prevent the type of plundering of art the Nazis undertook during World War II.

The fifth article, by Rolf-Dieter Hepp, opens again—also with regard to theorizing social quality - the debate about ontological and epistemological dimensions of relevant subjects of the SQA: in this case, the subject of precarization of labor circumstances and consequences and how this subject is approached in France and Germany. That means, which are the similarities and differences of assumptions, underlying both dimensions applied by scholars in both countries? A somewhat comparable comparison was made years ago in connection with the start of the theory of social quality by Graham Room (1995: 6). It concerned the difference between, in his terms, the approach of poverty, exclusion, and cohesion in for example the Anglo-Saxon world and the European Continental world. In the first case, poverty is closely associated with the liberal vision of society, under which relevant intellectual and political elites saw society as a Paretonian mass of atomized people engaged in competition within the marketplace In the second case, notions of poverty, and especially exclusion, and cohesion are inspired by Émile Durkheim In this tradition, society is seen by the intellectual and political elite as a status hierarchy or as several collectivities, bound together by sets of mutual rights and obligations that are rooted in some broader Durkheimian order. This input also gave a boost at the time to make an explicit distinction based on different studies (Herrmann et al. 2012: 73) of four conceptual frameworks that dominated Western human and societal sciences in the twentieth century.

The centerpiece concerns the understanding of the interaction of the constitutive interdependency (or dialectic) of processes of self-realization of human beings and the formation of a diversity of collective identities resulting to "the social and its quality" at a specific time of societies. This has a great deal of affinity with the aforementioned theme of fundamental tensions in a human society between "self and others," as discussed by Mukhopadhyay. Each framework is based on a specific understanding of the configuration of its ontological roots and epistemological characteristics. To be distinguished are (1) mechanical utilitarianism (Pareto c.s.), (2) constructive voluntarism 
(Weber c.s.), (3) dialectical materialism (Marx c.s.), and (4) structural functionalism (Durkheim c.s.). Based on this distinction is a hypothetical position determined from the ontological and epistemological characteristics of the social quality theory (Herrmann et al 2012). The assumption now is that the approach of a scientist who has affinity with the second conceptual framework cannot simply be compared to a scientist who, for example, has an affinity with the third framework. This question is relevant for Mukhopadhyay, who compares Sen with Marx. This question also plays also a role in Herrmann's article about human rights. Furthermore, Giri has raised an interesting point, namely that thee four conceptual frameworks are European (American) based. What to say and to think about current frameworks referred to in recent centuries in India, China, or Japan? Hepp's approach is not explicitly but certainly implicitly oriented on this subject of the conceptual frameworks.

But according to Hepp, this subject is more complicated. For example, the debate on precarization of labor conditions and consequences in Germany is based on the French discussion; however, it is oriented toward German models of discourse, which leads to different focuses and objectives. Even if in German contexts, the poverty situation and unqualified workers are the main topics of discussion. The French debate on precarization following Pierre Bourdieu, Robert Castel, Luc Boltanski, and Eve Chiapello focuses on precarization as a restructuring of labor relations. In this respect, a change of vectors is taking place here, which sets different priorities. These different emphases are connected with a different scientific self-image, which is broken in terms of scientific theory and is because it is rooted in the respective national traditions. Hepp argues that although the scientific exchange is universally oriented, it is split up by the different traditions in such a way that terms are assigned different meanings. In this article, especially Bourdieu plays an important role, because he made this question explicit. Because science is also covered by national traditions, scientific terms must first be transposed. The concept of discourse in Germany with Habermas and Apel is understood as speech and form of rational argumentation, whereas in France, with Michel Foucault, it is understood as intervention and change, that is, as social practice. Hepp chooses the case of precarization, which is becoming more and more important in contemporary times, also to explain the consequences for the use of different conceptual frameworks. And in this way, it provides an important stimulant for scholars concerned with the social quality approach to make new steps on a theoretical level. 


\section{References}

Apuzzo, M., S. Gebrekidan, and A. Armendariz. 2019. "Killer Slime, Dead Birds, an Expunged Map: The Dirty Secrets of European Farm Subsidies." New York Times, 25 December.

Brody, J. E. 2019. “The Crisis in Youth Suicide." New York Times, 12 December 12.

Cadman, T. 2019. "Why Australia Should Stop Burning Its Forests to Save Them.” Blog, 16 December. https://timcadman.wordpress.com/2019/12/16/why-australia-should-stop-burning-its-forests -to-save-them.

Cadman, T., K. Radunsky, A. Simonelli, and T. Maraseni. 2018. "From Paris to Poland: A Postmortem of the Climate Changed Negotiations." International Journal of Social Quality 8 (2): 27-47. https://doi.org/10.3167/IJSQ.2018.080203.

CIEL (Center for International Environmental Law). 2019. "Oil, Gas and the Climate: An Analysis of Oil and Gas Industry Plans for Expansion and compatibility with Global Emission Limits." 5 December. https://www.ciel.org/news/oil-gas-and-the-climate-an-analysis-of-oil-and-gas -industry-plans-for-expansion-and-compatibility-with-global-emission-limits.

Clay, K., and N. Z. Muller. 2019. "Recent Increases in Air Pollution: Evidence and Implications for Mortality.” NBER Working Paper no. 26381. https://www.nber.org/papers/w26381.

CPR (Center for Policy Research). 2017. "Air Pollution in Indian Cities: Understanding the Causes and the Knowledge Gaps." 14 December. https://cprindia.org/news/6569.

Curtin, S. C., and M. Heron. 2019. "Death Rates Due to Suicide and Homicide among Persons Aged 10-24: United States, 2000-2017.” NCHS Data Brief no. 352. https://www.cdc.gov/ nchs/products/databriefs/db352.htm.

Darrow, W. W. 2015. "The Decline and Disorganization of Public Health in the United States: Social Implications." International Journal of Social Quality 5 (2): 29-46. https://doi.org/10.3167/ IJSQ.2015.050203.

EC (European Commission). 2019/a. A European Green Deal: Striving to be the first climate-neutral continent. https://ec.europa.eu/info/strategy/priorities-2019-2024/european-green-deal_en.

EC (European Commission). 2019/b. The European Green Deal. COM(2019)640 final. Brussels: EC. https://ec.europa.eu/info/sites/info/files/european-green-deal-communication_en.pdf. Gebrekidan, S., M. Apuzzo, and B. Novak. 2019. "The Money Farmers: How Oligarchs and Populists Milk the E.U. for Millions." New York Times, 3 November.

Gebrekidan, S., M. Apuzzo and B. Novak. 2019. "The Money Farmers: How Oligarchs and Populists Milk the E.U. for Millions: The European Union spends 65 billion dollar a year subsidizing agriculture. But a chunk of that money emboldens strongmen, enriches politicians and finances corrupt dealing." New York Times, 3 November. https://www.nytimes.com/2019/11/03/world/ europe/eu-farm-subsidy-hungary.html

Giri, A. K. 2011. "Rethinking the Human and the Social: Towards a Multiverse of Transformations.” International Journal of Social Quality 1 (1): 91-109. https://doi.org/10.3167/ IJSQ.2011010109.

Greenpeace India, 2017. Airpocalypse: Assessment of Air Pollution in Indian Cities. Chennai: Greenpeace Environment Trust.

Herrmann, P., L. J. G. van der Maesen, and A. Walker. 2012. "Conceptual Location of Social Quality.” In Social Quality: From Theory to Indicators, ed. A. Walker, 70-94. London: Palgrave Macmillan.

xviii • International Journal of Social Quality • Volume 9, Issue $2 \bullet$ Winter 2019 
Hirschman, A. O. 1984. "Against Parsimony: Three Easy Ways of Complicating Some Categories of Economic Discourse." Bulletin of the American Academy of arts and Sciences 37 (8): 11-28.

Holman, D., and A. Walker. 2018. "Social Quality and Health: Examining Individual and Neighborhood Contextual Effects Using a Multilevel Modelling Approach." Social Indicators Research 138 (1): 245-270. https://doi.org/10.1007/s11205-017-1640-2.

IASQ (International Association on Social Quality). 2015. Manifesto for Paris climate conference. Amsterdam: IASQ. https://www.socialquality.org/wp-content/uploads/import/2015/11/sustainability_manifesto_23-11-2015.pdf

IASQ (International Association on Social Quality). 2019. Ideas and Suppositions about the Application and Elaboration of the 'Social Quality Approach' (SQA) in Eastern Europe: The Case of Ukraine. IASQ Working Paper Series no.17. https://socialquality.org/wp-content/uploads/ IASQ-Working-Paper-17-4.pdf.

Krugman, P. 2019. "Trump and his grand old party of pollution." New York Times, 16-17 November, 9. Meyer, S. B., T. C. N. Luong, P. R. Ward, and G. Tsourtos. 2010. "Operationalising the Theory of Social Quality: Analysis of the Reliability of an Instrument to Measure Social Quality." Development and Society 39 (2) : 329-358.

Milanovic, B. 2019. Capitalism, Alone: The Future of the System That Rules the World. Cambridge, MA: Belknap Press.

Milieudefensie. 2018. "Friends of the Earth Netherlands Sues Shell for Causing Climate Change." 6 March. https://en.milieudefensie.nl/climate-case-shell/friends-of-the-earth-netherlands -sues-shell-for-causing-climate-change.

Nijhuis, H. G. J. 2017. “Toward Comprehensive Conceptualizations of Contemporary Public Health: Participation as the Cornerstone of Appropriate Methodologies." International Journal of Social Quality 7 (2): 60-85. https://doi.org/10.3167/IJSQ.2017.070204.

Oberholzer, B. 2019. "Can Sustainable Finance Really Help Solve the Climate Crisis?" Social Europe, 10 December. https://www.socialeurope.eu/can-sustainable-finance -really-help-solve-the-climate-crisis.

OXFAM International. 2018. Richest 1 percent bagged 82 percent of wealth created last year - poorest half of humanity got nothing. https://www.oxfam.org/en/press-releases/richest-1-percent-bagged -82-percent-wealth-created-last-year-poorest-half-humanity

Partington, R. 2019. "Inequality: Is It Rising, and Can We Reverse It?” The Guardian, 9 September. Ricceri, M. 2019. "The Contribution of BRICS to the Quality of Global Development." International Journal of Social Quality 9 (2): 1-32. https://doi.org/10.3167/IJSQ.2019.090102.

Room, G. 1995. "Poverty and Social Exclusion: The New European Agenda for Policy and Research." In Beyond the Threshold: The Measurement and Analysis of Social Exclusion, ed. G. Room, 1-9. Bristol: Policy Press.

Russell, C. 2019. "Column-China and India Are Both the Problem and Solution for Coal, Climate Change.” Reuters, 13 November. https://www.reuters.com/article/column-russell-coal-iea/ column-china-india-are-both-the-problem-and-solution-for-coal-climate-change-russell -idUSL4N27U10R.

Stiglitz, J. 2019. "The end of neoliberalism and the rebirth of history”. Social Europe. https://www. socialeurope.eu/the-end-of-neoliberalism-and-the-rebirth-of-history

UN. 2015. Transforming Our World: The 2030 Agenda for Sustainable Development. New York: United Nations. 
UNEP (United Nations Environment Programme). 2019. Emissions Gap Report 2019. Nairobi: UNEP.

van der Maesen, L. J. G., and H. G. J. Nijhuis. 2000. "Continuing the Debate on the Philosophy of Modern Public Health: Social Quality as a Point of Reference." Journal of Epidemiology \& Community Health 54 (2): 134-142. http://dx.doi.org/10.1136/jech.54.2.134.

Ward, P. R., F. Verity, S. B. Meyer, and T. K. Gill. 2011. "Complex Problems Require Complex Solutions: The Utility of Social Quality Theory for Addressing Social Determinants of Health." BMC Public Health 11 (1): 630. https://doi.org/10.1186/1471-2458-11-630.

Ward, P. R., L. Mamerow, and S. B. Meyer. 2014. "Interpersonal Trust across Six Asia-Pacific Countries: Testing and Extending the 'High Trust Society' and 'Low Trust Society.'” PLoS ONE 9 (4). https://doi.org/10.1371/journal.pone.0095555.

Watts, J. 2019. “Amazon Fires 'Extraordinarily Concerning,' Warns UN Biodiversity Chief. Biodiversity Chief Calls for Countries to Halt Rapid Degradation of Nature." The Guardian, 30 August.

Watts, J., J. Ambrose, and A. Vaughan. 2019. "Oil Firms Pour Extra 7m Barrels per Day into Markets, Data Shows." The Guardian, 10 October.

Webster, W. 2019. "I Headed the F.B.I. and C.I.A.: There's a Dire Threat to the Country I Love." New York Times, 16 December. 